\title{
Praktijk Praktijk
}

\section{Proefimplementatie van het PRIMA antipestbeleid op basisscholen}

Femke Hoekstra ${ }^{1}$, Josien ter Beek ${ }^{2}$, Karin Wiefferink ${ }^{3}$, Goof Buijs ${ }^{4}$

Pesten op school komt veel voor. Pesten kan negatieve gevolgen hebben voor de gezondheid van kinderen. In Nederland bestaan dan ook meerdere, vaak regionale initiatieven om pesten aan te pakken. Van deze initiatieven is echter niet bekend of ze effect hebben. Bovendien gaat het vaak om kortdurende activiteiten, zoals een projectweek, waarvan het eventuele effect na enige tijd weer verdwijnt. In dit artikel wordt de implementatie van het PRIMA project beschreven. Het PRIMA project is gericht op het verder ontwikkelen, implementeren en evalueren van een effectief gebleken antipestbeleid in het basisonderwijs in $\mathrm{Ne}$ derland.

\section{HET PRIMA PROJECT}

Uit onderzoek van TNO Kwaliteit van Leven (TNO KvL) bleek dat 16,2\% van de kinderen in het basisonderwijs in Nederland zegt regelmatig te worden gepest. ${ }^{1}$ Geconcludeerd werd dat een integraal antipestbeleid de pestproblematiek op Nederlandse basisscholen effectief kan terugdringen. Maar ook bleek dat niet alle scholen alle activiteiten uitvoerden en dat de aandacht voor het antipestbeleid na enige tijd vaak verslapte. Effecten die na het eerste jaar van het project bereikt waren, vervaagden in het tweede jaar. Er moet dus gezorgd worden voor een structuur die niet alleen gericht is op

${ }^{1}$ Destijds onderzoeker bij TNO Kwaliteit van Leven

${ }^{2}$ Destijds project projectleider bij NIGZ

3 TNO Kwaliteit van Leven

${ }^{4} \mathrm{NIGZ}$ implementatie, maar ook gericht is op continering van het antipestbeleid.

Als vervolg op het onderzoek zijn NIGZ en TNO KvL, samen met GGD Nederland en Edventure (vereniging van onderwijsadviesbureaus), in 2004 het PRIMA project gestart. PRIMA staat voor: 'proefimplementatie antipestbeleid in het basisonderwijs'. Op 27 basisscholen in de GGD-regio's Zuidhollandse Eilanden en Nieuwe Waterweg Noord wordt in groep 6, 7 en 8 in een pilot met het PRIMA Antipestprogramma gewerkt. De scholen worden hierbij ondersteund door GGD Zuidhollandse Eilanden, GGD Nieuwe Waterweg Noord en Centrum voor Educatieve Dienstverlening (CED) Nieuwe Waterweg Noord.

Om de effectiviteit van het PRIMA antipestbeleid te vergroten is in de uitwerking van het PRIMA project rekening gehouden met de valkuilen die in eerdere implementatie-onderzoeken zijn gevonden. Alle onderdelen van het PRIMA antipestbeleid zijn gestructureerd en geprotocolleerd, zodat deze eenvoudiger in een jaarlijks terugkerend antipestbeleid van de school kunnen worden ingevoerd, gerealiseerd en gemonitord. Daarnaast worden de scholen bij de uitvoering en continuering van het antipestbeleid intensief begeleid vanuit een samenwerking van regionale organisaties: GGD'en en CED'en.

De basis voor het PRIMA antipestbeleid Het PRIMA antipestbeleid is gebaseerd op het effectief gebleken pestpreventieprogramma van de Noorse pestdeskundige Dan Olweus. Het originele programma van Olweus is een preventieprogramma gericht op het voorkomen en terugdringen van pestgedrag onder leer- lingen op basisscholen en middelbare scholen (leerlingen van 6 tot 15 jaar oud) en het verbeteren van hun onderlinge relaties. Het programma probeert de bestaande schoolomgeving zo te herstructureren dat de mogelijkheden en beloningen voor pesten verkleind worden. In Noorwegen heeft de invoering (op 42 scholen) van dit interventieprogramma geleid tot een afname van het pestgedrag op de scholen met 50 procent of meer. $^{2}$ Ook ander antisociaal gedrag, zoals vandalisme en spijbelen, nam af. Daarnaast verbeterde het sociale klimaat in de klas.

Bij de ontwikkeling van het PRIMA antipestbeleid is uitgegaan van de meest actuele handleiding voor leraren van het effectieve Pest Preventie Programma van Olweus (2001). De maatregelen op drie niveaus (school, groep en individu) die Olweus beschrijft, zijn nauwgezet gevolgd. Om pestproblemen systematisch aan te pakken is het volgens Olweus belangrijk om op alle drie de niveaus te werken. ${ }^{3}$ Vanzelfsprekend zijn de maatregelen aangepast aan de Nederlandse situatie. Naast het pestpreventie programma van Olweus is bij de ontwikkeling van het PRIMA antipestbeleid gebruik gemaakt van een Vlaamse uitwerking van het programma van Olweus: Pesten op school, Een actieprogramma ${ }^{4}$ en van het Nederlandse Nationaal Onderwijsprotocol tegen Pesten. ${ }^{5}$

In acht focusgroepen zijn de onderdelen van het PRIMA antipestbeleid voorgelegd aan leerkrachten, directeuren en interne begeleiders van basisscholen uit de twee GGD-regio's die aan het onderzoek deelnemen. Tijdens de bijeenkomsten is geïnventariseerd hoe docenten en schoolleiders aankeken tegen het 
programma van Olweus en wat zij zelf verwachtten van een antipestbeleid. De deelnemers gaven aan dat zij het bestaande programma moeilijk uitvoerbaar achtten vanwege de grote omvang. Ook noemden ze als twee belangrijke voorwaarden om met een antipestbeleid aan de slag te gaan de eigen motivatie om iets aan pesten te doen en vaardigheden om met pestproblemen om te gaan. Een training voor docenten over het omgaan met pestincidenten vonden zij daarom belangrijk. De opmerkingen vanuit de scholen zijn meegenomen bij het ontwerpen van de conceptmaterialen.

Op basis van de schriftelijke bronnen en de informatie uit de focusgroepen is een voorlopige versie van de materialen voor scholen gemaakt. Deze versie is in een tweede ronde focusgroepen van dezelfde samenstelling besproken in zes bijeenkomsten. Tips uit deze focusgroepen werden gebruikt om de handleiding definitief vorm te geven. Op basis hiervan zijn de materialen verder verbeterd.

Dit heeft geleid tot de samenstelling van het PRIMA pakket waar activiteiten voor de school op drie niveaus zijn beschreven (zie kader). Deze staan in een toegankelijke, complete handleiding voor docenten. Voor de leerlingen is een leerlingenboek ontwikkeld voor bij de lessen.
De implementatie van het PRIMA antipestbeleid

De kwaliteit van de materialen van het PRIMA antipestbeleid garandeert niet dat het beleid op de scholen ingevoerd en gecontinueerd zal worden. Uit implementatieonderzoek is gebleken dat materialen niet altijd gebruikt worden en de intensiteit van het gebruik afneemt. ${ }^{6}$ Daarom nemen de implementatie en continuering van het PRIMA antipestbeleid een belangrijke plaats in binnen het PRIMA project.

\section{Ondersteuning van scholen door de GGD} en onderwijsbegeleidingsdienst De regionale GGD en de onderwijsbegeleidingsdienst (bij dit project CED) spelen als begeleider van de scholen een noodzakelijke rol in de implementatie van het PRIMA antipestbeleid. Voor een succesvolle implementatie zijn instrumenten nodig die docenten ervan overtuigen dat het wenselijk is een lesmethode te gaan gebruiken, die hen ertoe aanzetten deze op een juiste manier toe te passen en die hen bij deze toepassing ondersteunen. De begeleiding van de scholen is, in navolging van Rogers, gericht op drie fasen in het implementatieproces: de adoptiefase, de implementatiefase en de continueringsfase. $^{7}$

In de adoptiefase staat de werving van de scholen voor het PRIMA project centraal. Het NIGZ heeft de regionale organisaties hiervoor ondersteunende materialen aangeleverd, zoals voorbeeldwervingsbrieven en een adoptiefolder. De werving heeft eind schooljaar 2004/ 2005 plaatsgevonden. In beide proefregio's is de werving van scholen soepel verlopen. Al voor de start van de werving had een aantal scholen zich als deelnemer aangemeld: deze scholen hadden via de focusgroepen of de schoolverpleegkundige al van het PRIMA project gehoord. Uit onderzoek bleek dat scholen waar pesten veel voorkomt, vaker geïnteresseerd waren in deelname dan scholen waar dat minder voorkomt. Scholen die al veel doen aan pestpreventie, waren minder geïnteresseerd. Tot slot bleek dat scholen meer geïnteresseerd waren in deelname als zij de indruk hadden dat de ouders, het bestuur van de school, de docenten en de leerlingen deelname een goed idee vonden.

Tijdens de implementatiefase hebben de GGD- en CED-medewerkers scholen getraind en ondersteund om hen voor te bereiden op het invoeren van het PRIMA antipestbeleid.

De bovenbouwdocenten hebben drie trainingsmiddagen gevolgd. Het PRIMA antipestbeleid is op de scholen in twee fasen ingevoerd: het eerste half jaar zijn

Aandachtspunten in het PRIMA antipestbeleid

\section{PRIMA antipestbeleid op schoolniveau.}

- Het maken van een invoeringsplan voor de verschillende onderdelen van het PRIMA antipestbeleid op school.

- Het opzetten van een Kernteam Pesten dat de invoering van het PRIMA antipestbeleid coördineert.

- Het instellen van een schoolbrede gedragscode over het omgaan met pesten op school.

- Het organiseren van een schoolbrede ouderbijeenkomst over het project en over pesten in het algemeen.

- Het afnemen van de PRIMA pestmeter op internet bij alle leerlingen van de bovenbouw en het bespreken van de resultaten.

- Het organiseren van een startbijeenkomst van het PRIMA project op de school.

\section{PRIMA acties in de groep, waaronder vallen:}

- Het maken van groepsregels over pesten in de groep.

- Het voeren van groepsgesprekken over de groepsregels.

- Het geven van een lessenserie over pesten in de groepen 6, 7 en 8.

- Het organiseren van een ouderbijeenkomst per groep.

PRIMA maatregelen om het pesten te stoppen, waaronder vallen:

- Het instellen van een surveillanceplan.

- Het onmiddellijk ingrijpen als er gepest wordt.

- Het systematisch onderzoeken van vermoedens van pesten.

- Het voeren van gesprekken met ouders en leerlingen, als er daadwerkelijk gepest wordt.

- Het doorverwijzen van leerlingen naar hulpverlenende instanties, wanneer blijkt dat ze niet op de bovengenoemde manieren geholpen kunnen worden. 
PRIMA acties op schoolniveau en PRIMA acties op groepsniveau ingevoerd. Vervolgens is begonnen met het invoeren van het derde onderdeel op individueel niveau: PRIMA maatregelen om pesten te stoppen. De fasering van de scholing en ondersteuning sloot hierbij aan. Voor deze fasering is gekozen om de scholen meer tijd te geven voor het invoeren van de verschillende onderdelen en het volgen van de trainingen van de GGD en/of CED.

De continueringfase is erop gericht om het PRIMA antipestbeleid op te nemen in het beleid van de school en in de dagelijkse praktijk op school.

Om scholen te kunnen begeleiden bij het invoeren van het PRIMA antipestbeleid werden de medewerkers van de GGD en CED ondersteund door het NIGZ en hebben zij een vierdaagse training gevolgd.

\section{Digitale regionale ondersteuning} Om alle betrokkenen bij het PRIMA project te ondersteunen in de uitvoering van het project is de PRIMA website ontwikkeld. De website is alleen toegankelijk voor direct betrokkenen bij het project en dient als virtuele omgeving om de communicatie tussen de betrokkenen te bevorderen. De site bevat nieuwsberichten, achtergrondinformatie, materialen en verhalen met ervaringen van scholen. Daarnaast verschijnt gedurende de proefimplementatie van het PRIMA antipestbeleid, twee keer per jaar een nieuwsbrief (PRIMA Nieuws).

\section{Begeleidend onderzoek van TNO KvL} Om te onderzoeken of het PRIMA Antipestbeleid inderdaad voldoende uitgewerkt en gestructureerd is en als continu beleid wordt toegepast en ook het pesten kan terugdringen voert TNO KvL een begeleidend implementatie- en effectonderzoek uit. Het implementatieonderzoek moet inzicht verschaffen in de belemmerende en bevorderende factoren ten aanzien van de werving van de scholen en de implementatie van het PRIMA antipestbeleid op basisscholen. Ook wordt onderzocht welke activiteiten van het PRIMA antipestbeleid op de scholen zijn uitgevoerd. Daarnaast wordt de ef- fectiviteit van het PRIMA antipestbeleid onderzocht, door op meerdere momenten te meten hoe vaak pesten voorkomt.

Er worden gegevens verzameld bij leerlingen, docenten, directies, en begeleiders van GGD en CED. De gegevens van het begeleidende onderzoek worden gebruikt om te beoordelen of het PRIMA pakket na de proefimplementatie landelijk geïmplementeerd kan worden.

\section{Eerste onderzoeksgegevens}

Uit de eerste meting onder leerlingen van deelnemende scholen bleek dat 12,9\% minimaal één keer per week wordt gepest. Hierbij is gebruik gemaakt van een digitale vragenlijst, de PRIMA pestmeter. Dit cijfer komt overeen met eerdere onderzoeken. Verder bleek dat uitschelden, uitlachen en belachelijk maken de meest voorkomende vormen van pesten zijn. Pesten via internet is een van de minst voorkomende vormen van pesten bij kinderen van de basisschool, terwijl docenten juist aangeven een grote behoefte te hebben aan informatie en methoden over internet pesten. Waarschijnlijk komt dit doordat pesten via internet een relatief nieuwe en onbekende vorm van pesten is.

Uit interviews met docenten bleek dat zij positief zijn over de lesmaterialen, omdat er veel verschillende en leuke werkvormen in zitten. Het uitvoeren van rollenspelen vinden de docenten wel lastig. Het leerlingenboekje wordt leuk gevonden, maar docenten vinden het wel jammer dat het één boekje is voor drie jaren. Groepsregels zijn in bijna alle groepen opgesteld. Deze regels werden zelden structureel besproken, maar wel naar aanleiding van incidenten. Verder geven sommige scholen aan dat het lastig is dat PRIMA alleen voor de bovenbouw is: zij hebben liever een programma wat voor alle groepen geschikt is. Meer ervaringen van scholen en van de begeleidende organisaties zijn te lezen in het PRIMA Nieuws. Deze nieuwsbrief is voor buitenstaanders te downloaden via het openbare dossier over het PRIMA project op de site van het NIGZ: www.nigz.nl. Nieuwe ontwikkelingen in het PRIMA project en de eerste onder- zoeksresultaten zullen ook hier te vinden zijn.

Het PRIMA project wordt in maart 2008 afgerond. Afhankelijk van de uitkomsten van het onderzoek naar de effectiviteit van het PRIMA pakket zal het pakket vervolgens landelijk worden verspreid.

\section{Noot}

Het PRIMA project is een samenwerking tussen het NIGZ, TNO Kwaliteit van Leven, EDventure, GGD Nederland, GGD Nieuwe Waterweg Noord, CED Nieuwe Waterweg Noord en de GGD Zuidhollandse Eilanden. Het wordt gefinancierd door ZonMw.

\section{LITERATUUR}

1. Fekkes M. Bullying among elementary school children. The Netherlands: De Brink, 2005.

2. Olweus D. Bullying at school, what we know and what we can do. Oxford UK: Blackwell Publishing, 1993.

3. Olweus D. Bullying at school. Basic facts and an effective intervention program. Promotion Education 1994; 1:27-31.

4. Stevens $V$, Oost P van. Pesten op school. Een actieprogramma. Handboek voor de begeleider. Leuven Apeldoorn: Garant Uitgevers nv, 1998.

5. Meer $B$ van der. Nationaal onderwijsprotocol tegen pesten. Almere: Landelijke Werkgroep Pesten, 1996.

6. Paulussen T, Wiefferink K. Implementatie is geen vanzelfsprekendheid. JGZ 2003;4,68-71.

7. Rogers EM. Diffusion of innovations. New York: The Free Press, 1995.

CORRESPONDENTIEADRES Karin Wiefferink, TNO Kwaliteit van Leven, Postbus 2215, 2301 CE Leiden, tel. 071-5181654, e-mail: Karin.wiefferink@tno.nl 